УДК 621.372 .543 .2

\title{
МАТЕМАТИЧЕСКАЯ МОДЕЛЬ ЦИФРОВЫХ ФИЛЬТРОВ ЧАСТОТНОЙ ВЫБОРКИ СО СМЕЩАЕМОЙ ФАЗОЧАСТОТНОЙ ХАРАКТЕРИСТИКОЙ
}

\author{
ШАКУРСКИЙ М. В., ВОЛОВАЧ В. И. \\ Поволжский государственньй университет сервиса, \\ Россия, Тольятти, 445677, ул. Гагарина, 4
}

\begin{abstract}
Аннотация. В статье приведены математические модели цифровых фильтров частотной выборки со смещаемой фазочастотной характеристикой (ФЧХ) и обобщенная математическая модель, учитывающая смещение ФЧХ, вносимое на входе. Проведенные исследования позволили разработать класс узкополосных фильтров с возможностью как смещения ФЧХ, так и изменения мгновенной фазы выходного сигнала в реальном времени.
\end{abstract}

Ключевые слова: цифровой фильтр; метод частотной выборки; фазочастотная характеристика; ФЧХ; элементарный цифровой фильтр; конечная импульсная характеристика

\section{ВВЕДЕНИЕ}

Исследования измерительных автоколебательных преобразователей девиации фазы и частоты, работающих в режиме повышенной чувствительности [1-3] показали необходимость синтеза цифровых фильтров (ЦФ) с перестраиваемой фазочастотной характеристикой (ФЧХ). Известно, что ФЧХ цифровых фильтров выходит из нуля, а угол ее наклона определяется длительностью импульсной характеристики, что усложняет, а в большинстве случаев делает невозможной настройку цифровой автоколебательной системы [4].

Проведенные исследования позволили синтезировать класс ЦФ со смещаемой ФЧХ $[5,6]$, позволяющие не только настраивать

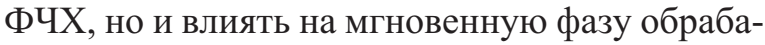
тываемого сигнала [7]. В данной статье предложена обобщенная математическая модель ЦФ со смещаемой ФЧХ.

\section{МАТЕМАТИЧЕСКАЯ МОДЕЛЬ ЦФ ЧАСТОТНОЙ ВЫБОРКИ}

В основе реализации любого алгоритма цифровой фильтрации лежит его математическое описание [8]. Рассмотрим различные способы смещения ФЧХ цифровых КИХ-фильтров на основе метода частотной выборки и скользящего дискретного комплексного преобразования Фурье. Получим математические модели для ЦФ без смещения ФЧХ $[9,10]$, и ЦФ со смещением ФЧХ.

Рассмотрим работу элементарного цифрового фильтра (ЭЦФ) на основе скользящего дискретного комплексного преобразования Фурье $[8,9,11,12]$. Для этого получим выражение, позволяющее найти значение отсчета выходного сигнала по известной скользящей выборке отсчетов входного сигнала.

Отсчет выходного сигнала формируется на каждом интервале дискретизации последним отсчетом сигнала, полученного в результате обратного преобразования Фурье [9]: 


\section{БИБЛИОГРАФИЧЕСКИЙ СПИСОК}

1. Иванов, В.В. Генераторные фазовые и частотные преобразователи и модуляторы / В.В.Иванов, В. К. Шакурский. - М. : Радио и связь, 2003. - 184 с.

2. Иванов, В. В. Синтез цифровых фильтров для генераторных преобразователей повышенной чувствительности / В.В.Иванов, М.В.Шакурский, В. К. Шакурский // Приборостроение. - 2012. - Т. 55, № 7. - С. 28-31. - (Известия вузов). - Режим доступа : http://pribor.ifmo.ru/ru/article/6078/sintez_cifrovyh_filtr ov dlya generatornyh preobrazovateley povyshennoy chuvstvitelnosti.htm.

3. Патент 113597 РФ, МПК G06F 17/14. Цифровой фильтр со смещаемой фазочастотной характеристикой / В. К. Шакурский, М. В. Шакурский (Россия) ; опубл. 20.02.2012, Бюл. № 5.

4. Шакурский, М.В. Цифровые фильтры частотной выборки / М. В. Шакурский, В. В. Иванов. - Самара : СНЦ РАН, 2012. - 106 c.

5. Айфичер, Э.С. Цифровая обработка сигналов: практический подход / Э. С. Айфичер, Б. У. Джервис : пер. с англ. - М. : Вильямс, 2004. — 990 с.

5. Harris, S. P. Automatic design of frequency sampling filters by hybrid genetic algorithm techniques / S. P. Harris, E. C. Ifeachor // IEEE Trans. Signal Process. - Dec. 1998. - Vol. 46, No. 12. - P. 3304-3314. DOI : $\underline{10.1109 / 78.735305}$.

6. Rabiner $L$. An approach to the approximation problem for nonerecursive digital filters / L. Rabiner, B. Gold, C. McGonegal // IEEE Trans. Audio Electroacoustics. - Jun. 1970. - Vol. 18, No. 2. - P. 83-106. - DOI : 10.1109/TAU.1970.1162092. 